\title{
POTENTIAL CONFLICTS IN THE LAND-USE PLANNING PROCESS: A CASE STUDY OF THE RURAL COMMUNE OF OLEŚNICA (POLAND)
}

\author{
Anna GrochowsKa $\odot$, Martyna Matecka \\ Department of Spatial Management, University of Wroclaw, Poland \\ Manuscript received: February 10, 2020 \\ Revised version: April 6, 2020
}

\begin{abstract}
Grochowska A., Matecka M., 2020. Potential conflicts in the land-use planning process: A case study of the rural commune of Oleśnica. Quaestiones Geographicae 39(2), Bogucki Wydawnictwo Naukowe, Poznań, pp. 129-137. 3 figs, 3 tables.

ABSTRACT: The purpose of this study was to identify compatibilities of land-use patterns resulting from adjacent functions within the rural commune of Oleśnica. The analysis was made based on the relevant studies of conditions and directions of spatial planning, as well as a field inventory. The results of the studies show that the applicable planning document became a potential source of spatial conflicts. On these grounds, a negative assessment was given to the functioning spatial planning system, which, according to the premises of spatial order and sustainable development, should prevent them. The existing incompatibilities are the result of issues with coordination of the local spatial policies. As a consequence, they cause an urban development chaos, lack of proper space shaping, environmental damage and lower the residents' quality of life.
\end{abstract}

KEYWORDS: spatial conflicts, spatial planning, sustained development, Oleśnica rural commune

Corresponding author: Anna Grochowska, Faculty of Earth Sciences and Environmental Management, University of Wroctaw, ul. Kuźnicza 49/55, 50-138 Wrocław, Poland; e-mail: anna.grochowska@uwr.edu.pl

\section{Introduction}

Land use conflict is a complex problem following countless risk factors as a result of rapid socio-economic development and urbanisation (Allen 2003; Antrop 2004; Zhou et al. 2019). The dynamic socio-economic growth observed in Poland after its accession to the EU in 2004 affected intensive changes in the spatial development of the country. The results are an increase in incompatibility between the functions of adjacent zones and the related emergent threats of spatial conflicts. In particular, this concerns grounds located in the metropolitan systems of the largest cities in the country, especially those connected with rural areas (Lisowski, Grochowski 2009).
Grounds located along administrative borders of communes are particularly exposed to this phenomenon, as they are a meeting area of various, and not always coherent, local spatial policies. Land-use planning decisions have potential for generating conflicts due to negative impacts on the environment and community (Kaya, Erol 2016).

This phenomenon has not been sufficiently investigated, particularly from the perspective of identifying the scale and nature of the existing incompatibilities. The scale and nature of the existing compatabilities is also very important in the context of a coherent spatial policy and prevention of spatial conflicts, which cause negative social, economic and environmental 
consequences ( $c f$. Furmankiewicz, Potocki 2004; Głogowski et al. 2013; Gołąb-Korzeniowska 2008; Gonda-Soroczyńska 2009; Hajduk 2010; Hibszer, Partyka 2005; Jabłoński, Mazurkiewicz 2014; Kistowski 2008; Tokajuk 2011). Land use conflict occurs whenever land-use stakeholders have incompatible interests related to land areas that result in negative effects (von der Dunk et al. 2011).

The purpose of this study was to identify the compatibilities of land-use patterns resulting from adjacent functions that were specified during field studies. The research focused on spatial aspects - mapping hot spots of potential land-use conflicts. Mechanisms for coordinating local spatial policies do not prevent the emergence of spatial conflicts at municipal borders. The identification method is important to better understand the types of actions in the field of planning and competing stakeholder values.

The time frame of the study includes the status as of the end of 2016, when field-inventory-related works were completed. The spatial scope encompasses areas along the administrative borders of the rural communes of Oleśnica.

Sustainable development and spatial order as intended by the legislature are, for the authorities' elusive goal of efficient and comprehensive spatial policy. Once achieved, this goal affects the quality of the residents' life and the protection of valuable natural resources, while leading to economic development. Moreover, efficient spatial policy tools may contribute to new investments, which will bring numerous benefits to a commune and the adjacent regions (Gwiazdowicz et al. 2008). Local governments frequently fail to adhere to the basic premises connected with the proper operation of a spatial policy, thus generating spatial chaos. In Poland, there has recently been an increasing number of incompatible landuse patterns, collisions of functions and spatial conflicts. According to Ułańska and Borkowska (2013), functional incompatibility occurs whenever adjacent lands have different purposes. In turn, conflicts occur when 'one side wants to retain a specific function of the given territory (place) and the other intends to change it, or when both sides want to change the specific status (function), but the purposes or means of the change are understood differently' (Furmankiewicz, Potocki 2004: 7 ). The aim of spatial planning is to meet current and future societal needs while keeping landuse conflict contained and functional (Brown, Raymond 2013).

Jędraszko (2008) emphasised that the Polish planning law favours the fast development of undeveloped and peripheral lands without accounting for the general interest of the urban area, which increases spatial chaos. The existing functional incompatibilities and spatial conflicts raise grave reservations of numerous scientists and authors; therefore, they are often the object of research, with numerous publications focusing on naturally-valuable areas.

Another sizable group consists of works concerning areas related to the phenomena of urbanisation and suburbanisation. As mentioned before, Grochowska (2016) as well as Ułańska and Borkowska (2012) analysed conflicts which occur in metropolitan areas. At the same time, they determined that in order to restrict adverse phenomena occurring in space and to improve the quality of spatial planning it is necessary to improve the qualifications of public authorities and planners. The authors emphasised that the existing functional collisions and spatial conflicts result from the faulty functioning of the spatial planning system as demonstrated by inconsistencies in legal regulations and planning procedures, low awareness of residents in the scope of a spatial economy, and the frequent incompetence of local government bodies ( $c f$ Furmankiewicz, Potocki 2004; Przewoźniak 2007; Puk 2011; Wdowicka, Mierzejewska 2012).

\section{Methods}

\section{Study area}

The Oleśnica rural commune is located in the north-east part of the Lower Silesian province, about $25 \mathrm{~km}$ from Wrocław (Poland). The commune is part of the Wrocław Metropolitan Area $(\mathrm{WrOM})$ and shows functional and spatial connections with Wroclaw, e.g. related to a daily commute and the development of residential and economic functions. To achieve the purpose of this study, areas along the internal border of the commune $(27 \mathrm{~km})$ with Oleśnica city were investigated, in addition to those along the internal border $(150 \mathrm{~km})$ with eight adjacent communes. 
Four of the investigated communes are part of the WrOM (Czernica, Dobroszyce, Długołęka, Twardogóra), and the remaining units (Bierutów, Dziadowa-Kłoda, Jelcz-Laskowice, Syców) run along the outer border of the WrOM (Fig. 1). This allows investigation of the incompatibility phenomenon at the junction of highly different areas, characterised by a diverse intensity of functional connections.

Factors related to its convenient location have the greatest effect on the development of the Oleśnica commune. This area is under strong influence from Wrocław and the city of Oleśnica, while a well-developed transport infrastructure facilitates the use of external developmental stimuli. Another important advantage is a large surface area of available land, which can be allocated for new investments related to residential or service-industrial functions.

Internal migrations in the investigated area are mostly related to the movement of people from nearby cities. Therefore, it may be said that an increase in the number of residents of the Oleśnica rural commune is related to its proximity to Wrocław. Moreover, the positive balance of migration in rural areas is becoming increasingly common and visible throughout Poland, particularly in suburban areas.

At present, there are 23 local spatial development plans within the administrative borders of the commune. Yet, for spatial planning, a more accurate measure is the data defining the size of the area subject to the local spatial development plan. In the case of the Oleśnica commune, as much as $62 \%$ of the total surface area is subject to the local plans, which is high compared to the value for rural communes in Poland $(30 \%)$. The significant coverage of the local plans proves that the commune conducts an aware, well-organised spatial policy, preparing its lands for new investments - the existence of a plan defines the functions for a given area and facilitates real estate trade and investment activities.

The existing land-use patterns are determined by natural and economic factors. Most land within the borders is arable $-69.4 \%$, followed by: forest and wooded land $-23.7 \%$, developed and urbanised land $-4.5 \%$. The land-use structure indicates that the commune is a typically rural one. Due to the increasing number of residents, one may suppose that the share structure of individual land will change in the future. The phenomena of changing the designation of arable land and forests for non-agricultural and non-forest purposes are related to the increasing number of residents, and the resulting need for increased areas for development. New residents in the rural areas necessitate development and construction of new settlements, mostly single-family buildings. Since 2008, the number of residential buildings grew from 2,250 to 3,079, as of 2015. Moreover, between 2000 and 2015, the number of residential rooms doubled and the useable surface area of the apartments increased.

The economic potential of the commune affects the residents' standard of living and the possibilities of economic development. The convenient location and well-developed transport infrastructure favour the emergence of new companies and increase the commune's chances of attracting new, outside investors. In the investigated area, since 2000 the number of business entities have been growing at a faster rate than the country's average.

Taking into account the entrepreneurship rate (i.e. the number of business entities per 1,000 residents), it can be said that the commune has a high development potential compared to the entire country. Since 2000, one can observe the high dynamics of entrepreneurship growth - in 2015, the entrepreneurship rate was higher than

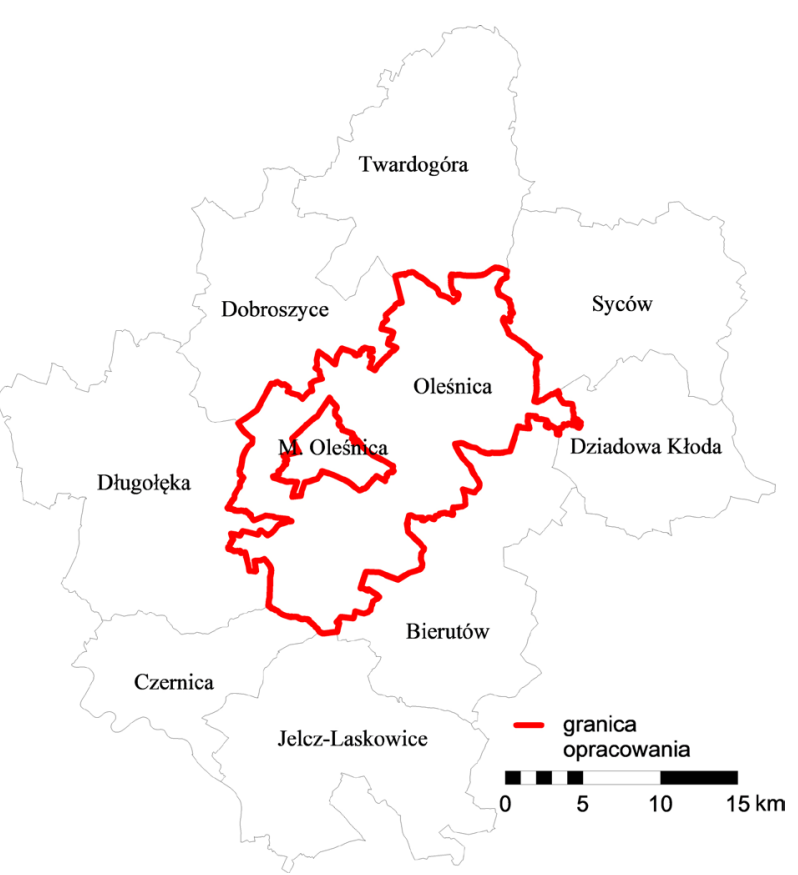

Fig. 1. Study area - as of 2016. Source: own study. 
the average value for rural communes in Poland, slowly approaching the average value for Poland as a whole.

These characteristic factors indicate a very intensive change in the socio-economic conditions of the commune development. This change has significantly affected the shape of spatial development. This situation may cause numerous incompatibilities in land development or contribute to the emergence of intensive spatial conflicts.

\section{Compatibility of functions}

This study concerns issues related to the shaping and implementation of the spatial policy by local authorities. The spatial policy is implemented using several primary instruments, the most crucial being the study of conditions and targets of spatial planning, which is a precise outline of the directions of the local commune's spatial policy and the local plan ${ }^{1}$. The starting point for the aforementioned research process was to adopt the premise that the borders of individual communes are areas of potential spatial conflicts. This assumption results from the planning power of the commune, which conducts a spatial policy and runs an economy based on the study of conditions and directions of spatial planning of the commune (SUiKZP). It is mandatory to develop and enact the same. It is made for the entire commune area and may not cross its administrative borders - the commune may not decide the purpose and rules of development for grounds located outside its borders. It is also by no means obliged to adopt the directions of spatial development of the study for land in adjacent communes. Therefore, the areas of administrative borders of communes are considered likely to cause conflicts, as that is where the spatial policies conducted by the local authorities meet (Grochowska 2015, 2016).

The research procedure proposed by Grochowska (2016) was used for determining the compatibility of the existing functions. What was adopted was the premise that the areas of the potential spatial conflicts are the borders of individual communes.

Spatial Planning and Land Development Act of 27 March 2003 (Journal of Laws 2003, No 80, item 717).
The primary research materials were studies on spatial development conditions and directions for the Oleśnica rural commune and the adjacent communes. The studies differed in terms of the format, quality and time frame. Moreover, practically every commune used different notations and planning designations.

The collected study drawings were used to compile a map encompassing the areas on both sides of the administrative border of the Oleśnica rural commune. A field inventory was made after precisely defining the study area, and the actual development of the areas on both sides of the border was checked. Then, the degree of functional compatibility of the adjacent areas was specified on the basis of the documents and field studies. In order to investigate the coherence of the directions of spatial policies carried out by local authorities, the comparison and analysis of the regulations concerning land purposes were generalised and standardised. The letter designations and nomenclature of the land functions from the studies were converted into the nomenclature used in the Ordinance of the Minister of Infrastructure ${ }^{2}$ on the required scope of the local spatial development plan.

Another stage of the study was to determine the degree of compatibility of the ultimate purpose of the lands on both sides of the commune borders. This degree was determined on the basis of a land use compatibility matrix, as defined in the WrOM commune study by Grochowska (2016) (Table 1) and made in accordance with the research procedure conducted by Ułańska and Borowska (2013). In the matrix, individual combinations of land-use patterns were classified as compatible (0), incompatible (1) and causing potential conflict (2), whereas in this study, individual sections of land-use patterns were assigned as compatible, partially incompatible or incompatible. Incompatibility occurred if the matrix showed an incompatibility (1) and potential conflict (2). In turn, partial incompatibility resulted from a specific regulation present only in the study of the Oleśnica rural commune, which concerned areas intended for single-family

2 Ordinance of the Minister of Infrastructure of $26 \mathrm{Au}$ gust 2003 on the required scope of the project local development plan (Journal of Laws 2003, No 164, item 1587). 
Table 1. Compatibility matrix of land use allocations.

\begin{tabular}{|c|c|c|c|c|c|c|c|c|c|c|c|c|c|c|c|c|c|c|c|c|c|c|c|}
\hline & $\mathrm{Z}$ & $\sum$ & 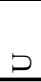 & $\tilde{s}$ & S & $\stackrel{s}{5}$ & $\sum_{z}^{2}$ & $\sum_{\Sigma}^{2}$ & $\simeq$ & $\stackrel{2}{\simeq}$ & $\sum$ & a & ֻ & $\mathrm{Z}$ & $\vec{N}$ & $\vec{N}$ & ㅇ & $\stackrel{\mathrm{N}}{\mathrm{N}}$ & 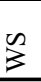 & $\underline{\theta}$ & 兰 & $\stackrel{N}{\ominus}$ & 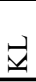 \\
\hline MN & 0 & 0 & 1 & 0 & 1 & 2 & 0 & 0 & 2 & 2 & 2 & 2 & 2 & 2 & 1 & 0 & 2 & 1 & 1 & 1 & 1 & 1 & 1 \\
\hline MW & 0 & 0 & 1 & 0 & 1 & 2 & 0 & 0 & 2 & 2 & 2 & 2 & 2 & 2 & 1 & 0 & 2 & 1 & 1 & 1 & 1 & 1 & 1 \\
\hline $\mathrm{U}$ & 1 & 1 & 0 & 1 & 0 & 0 & 1 & 1 & 1 & 1 & 1 & 0 & 0 & 2 & 1 & 1 & 1 & 1 & 1 & 0 & 0 & 1 & 0 \\
\hline US & 0 & 0 & 1 & 0 & 1 & 2 & 0 & 0 & 2 & 2 & 2 & 2 & 2 & 1 & 2 & 0 & 2 & 1 & 0 & 1 & 0 & 1 & 1 \\
\hline UC & 1 & 1 & 0 & 1 & 0 & 0 & 1 & 1 & 1 & 1 & 1 & 0 & 1 & 2 & 1 & 1 & 1 & 1 & 1 & 0 & 0 & 1 & 0 \\
\hline $\mathrm{U} / \mathrm{P}$ & 2 & 2 & 0 & 2 & 0 & 0 & 2 & 2 & 2 & 2 & 2 & 0 & 0 & 2 & 2 & 1 & 2 & 1 & 1 & 0 & 0 & 1 & 0 \\
\hline $\mathrm{MN} / \mathrm{U}$ & 0 & 0 & 1 & 0 & 1 & 2 & 0 & 0 & 1 & 1 & 2 & 2 & 2 & 2 & 1 & 0 & 2 & 1 & 1 & 1 & 1 & 1 & 1 \\
\hline $\mathrm{MW} / \mathrm{U}$ & 0 & 0 & 1 & 0 & 1 & 2 & 0 & 0 & 2 & 2 & 2 & 2 & 2 & 2 & 1 & 0 & 2 & 1 & 1 & 1 & 1 & 1 & 1 \\
\hline $\mathrm{R}$ & 2 & 2 & 1 & 2 & 1 & 2 & 2 & 2 & 0 & 0 & 0 & 2 & 2 & 0 & 0 & 0 & 0 & 0 & 0 & 1 & 0 & 0 & 0 \\
\hline $\mathrm{RU}$ & 2 & 2 & 1 & 2 & 1 & 2 & 2 & 2 & 0 & 0 & 0 & 2 & 2 & 1 & 0 & 1 & 0 & 1 & 1 & 1 & 0 & 1 & 1 \\
\hline $\mathrm{RM}$ & 2 & 2 & 1 & 2 & 1 & 2 & 2 & 2 & 0 & 0 & 0 & 2 & 2 & 1 & 0 & 0 & 0 & 1 & 1 & 1 & 0 & 1 & 1 \\
\hline $\mathrm{P}$ & 2 & 2 & 0 & 2 & 0 & 0 & 2 & 2 & 2 & 2 & 2 & 0 & 0 & 2 & 2 & 1 & 2 & 1 & 1 & 0 & 0 & 1 & 1 \\
\hline $\mathrm{PG}$ & 2 & 2 & 0 & 2 & 1 & 0 & 2 & 2 & 2 & 2 & 2 & 0 & 0 & 1 & 2 & 1 & 2 & 1 & 1 & 0 & 0 & 1 & 1 \\
\hline $\mathrm{ZN}$ & 2 & 2 & 2 & 1 & 2 & 2 & 2 & 2 & 0 & 1 & 1 & 2 & 1 & 0 & 0 & 0 & 0 & 0 & 0 & 1 & 1 & 0 & 1 \\
\hline ZL & 1 & 1 & 1 & 1 & 1 & 1 & 1 & 1 & 0 & 0 & 0 & 2 & 2 & 0 & 0 & 0 & 0 & 0 & 0 & 1 & 0 & 0 & 1 \\
\hline ZP & 0 & 0 & 1 & 0 & 1 & 1 & 0 & 0 & 0 & 1 & 0 & 1 & 1 & 0 & 0 & 0 & 0 & 0 & 0 & 1 & 0 & 1 & 0 \\
\hline ZD & 2 & 2 & 1 & 2 & 1 & 2 & 2 & 2 & 0 & 0 & 0 & 2 & 2 & 0 & 0 & 0 & 0 & 0 & 0 & 1 & 0 & 1 & 0 \\
\hline $\mathrm{ZC}$ & 1 & 1 & 1 & 1 & 1 & 1 & 1 & 1 & 1 & 1 & 1 & 1 & 1 & 0 & 0 & 0 & 0 & 0 & 1 & 0 & 0 & 1 & 1 \\
\hline WS & 1 & 1 & 1 & 0 & 1 & 1 & 1 & 1 & 0 & 1 & 0 & 1 & 1 & 0 & 0 & 0 & 0 & 1 & 0 & 0 & 0 & 0 & 0 \\
\hline KD & 1 & 1 & 0 & 1 & 0 & 0 & 1 & 1 & 1 & 1 & 1 & 0 & 0 & 1 & 1 & 1 & 1 & 0 & 0 & 0 & 0 & 0 & 0 \\
\hline TK & 1 & 1 & 0 & 0 & 0 & 0 & 1 & 1 & 0 & 0 & 0 & 0 & 0 & 1 & 0 & 0 & 0 & 0 & 0 & 0 & 0 & 0 & 0 \\
\hline $\mathrm{TZ}$ & 1 & 1 & 1 & 1 & 1 & 1 & 1 & 1 & 1 & 0 & 1 & 1 & 1 & 1 & 0 & 0 & 1 & 1 & 1 & 0 & 0 & 0 & 0 \\
\hline $\mathrm{KL}$ & 1 & 1 & 0 & 1 & 0 & 0 & 1 & 1 & 0 & 1 & 1 & 1 & 1 & 1 & 1 & 0 & 0 & 1 & 0 & 0 & 0 & 0 & 0 \\
\hline
\end{tabular}

Source: Grochowska 2016: 52-53.

Abbreviations used in the matrix: MN - Single-family residential development areas, MW - Multi-family residential development areas, U - Service development areas, US - Sports and recreation areas, UC - Areas for commercial facilities with retail space over 2,000 m², U/P - Service and production development areas, MN/U - Residential and service development areas, MW/U - , R - Farming areas, RU - Production service areas for arable land, livestock. Horticultural and fishing farms, RM - Homestead development areas in arable land, livestock and horticultural farms, P - Production facility, warehouse and storage areas, PG - Mining areas and lands, ZN - Uncontrolled greenery areas, ZL - Forests, ZP - Controlled greenery areas, ZD - Allotment garden areas, ZC - Cemeteries, WS - Surface water areas, KD - Road areas, TK - Railway lines and areas, TZ - Closed areas, KL - Civilian airport areas.

residential or homestead buildings. The ambiguity of this regulation prevents the precise definition of the compatibility of the purposes adjacent to this area. In fact, compatibility - or lack thereof - shall depend on what actually appears in a given area.

The last stage of the study procedure was a separate, detailed analysis and the characterisation of the determined incompatibilities for each pair of communes. General and final conclusions were formulated based on the results.

\section{Results}

The analysis was made for land-use patterns present along the border of the nine pairs of adjacent communes. As a result, a total of 255 sections with different land-use patterns were identified, including: based on the land purpose specified in the studies of conditions and directions of spatial planning, 79 sections were defined as incompatible, whereas a field inventory disclosed only 18 incompatible sections (Table 2). The identified sections with incompatible land-use 
patterns may become the sites of potential spatial conflicts. It is also worth noting that 'the land functions which are deemed incompatible may become conflicts, but not necessarily. Whereas compatibilities between land-use patterns are not tantamount to the lack and impossibility of conflicts. It may happen that apparently compatible functions come into conflict with each other' (Grochowska 2016: 14). The current incompatibilities demonstrated that the investigated area suffers from problems with coordination of the local spatial policies.

The biggest share of incompatibilities was found in the border between the commune of Oleśnica and the town of Oleśnica. The area was characterised by a high intensity of urbanisation and investment processes, hence the large diversity of designation of areas with potential incompatibilities. The town of Oleśnica is distinguished by its diversified land development. There are both production and agricultural areas, as well as intensive housing and forest development.

Both the study and field studies found no incompatibilities at the border between Oleśnica and Dziadowa Kłoda. On the remaining borders the sum of incompatibilities ranged from 1 to 15 , the smallest share of them concerned the communes: Jelcz-Laskowice and Czernica. It is worth noting that much more incompatibilities were determined on the basis of allocations included in the studies of conditions and directions of development of communes than in the real dimension. This may be due to the fact that not all the provisions of the study have been implemented. Analysing the border for each commune, 115 sections with different actual development were determined separately from the results of the analysed planning documents (Table 3 ).

The differences concerned mainly the areas used for agricultural purposes, while in the study

Table 2. Number of incompatible sections in border areas.

\begin{tabular}{|c|c|c|c|c|}
\hline No. & $\begin{array}{c}\text { Communes rural }(\mathrm{r}), \text { urban }(\mathrm{u}), \\
\text { urban-rural (ur) }\end{array}$ & $\begin{array}{l}\text { Number of connected } \\
\text { sections with different } \\
\text { functions }\end{array}$ & $\begin{array}{l}\text { Number of incompati- } \\
\text { ble sections (SUiKZP) }\end{array}$ & $\begin{array}{l}\text { Number of incompati- } \\
\text { ble sections } \\
\text { (actual development) }\end{array}$ \\
\hline 1 & Oleśnica (r) - Oleśnica (u) & 61 & 36 & 7 \\
\hline 2 & Oleśnica (r) - Długołęka (r) & 48 & 10 & 2 \\
\hline 3 & Oleśnica (r) - Dobroszyce (r) & 37 & 10 & 5 \\
\hline 4 & Oleśnica (r) - Bierutów (ur) & 36 & 7 & 0 \\
\hline 5 & Oleśnica (r) - Syców (ur) & 35 & 9 & 1 \\
\hline 6 & Oleśnica (r) - Twardogóra (ur) & 15 & 5 & 3 \\
\hline 7 & Oleśnica (r) - Dziadowa-Kłoda (r) & 10 & 0 & 0 \\
\hline 8 & Oleśnica (r) - Czernica (r) & 9 & 1 & 0 \\
\hline 9 & Oleśnica (r) - Jelcz-Laskowice (ur) & 4 & 1 & 0 \\
\hline \multicolumn{2}{|r|}{ Total } & 255 & 79 & 18 \\
\hline
\end{tabular}

Source: own study.

Table 3. Number of sections of consistent and inconsistent actual land use planning.

\begin{tabular}{|c|c|c|c|c|}
\hline \multirow[t]{2}{*}{ No. } & \multirow{2}{*}{$\begin{array}{c}\text { Communes rural (r), } \\
\text { urban (u), } \\
\text { urban-rural (ur) }\end{array}$} & \multirow{2}{*}{$\begin{array}{l}\text { Number of segments of differ- } \\
\text { ent functions connected }\end{array}$} & \multicolumn{2}{|c|}{$\begin{array}{l}\text { Is the real development consistent with the in } \\
\text { tended use of the land? }\end{array}$} \\
\hline & & & Yes & No \\
\hline 1 & Oleśnica (r) & 255 & 200 & 55 \\
\hline 2 & Oleśnica $(\mathrm{u})$ & 61 & 30 & 31 \\
\hline 3 & Długołęka (r) & 48 & 40 & 8 \\
\hline 4 & Dobroszyce (r) & 37 & 32 & 5 \\
\hline 5 & Bierutów (ur) & 36 & 30 & 6 \\
\hline 6 & Syców (ur) & 35 & 32 & 3 \\
\hline 7 & Twardogóra (ur) & 15 & 9 & 6 \\
\hline 8 & Dziadowa-Kłoda (r) & 10 & 10 & 0 \\
\hline 9 & Czernica (r) & 9 & 9 & 0 \\
\hline 10 & Jelcz-Laskowice (ur) & 4 & 3 & 1 \\
\hline & Total & 510 & 395 & 115 \\
\hline
\end{tabular}

Source: own study. 


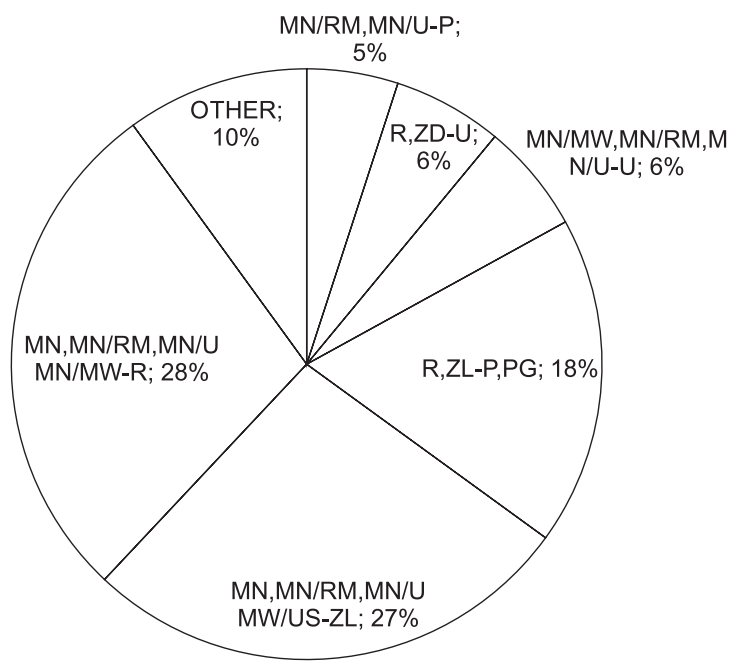

Fig. 2. Share of incompatibilities of land use allocations occurring on the border of the commune. Oleśnica - 2016.

Source: own study.

the area was intended for single-family housing and there was afforestation instead of arable land.

When studying the incompatibilities determined on the basis of the studies, the most frequent incompatibilities (55\%) concerned the areas of housing function (multi-family, single-family or/and homestead), housing and service function with the area of agricultural and forest function (Fig. 2). Subsequent incompatibilities appeared in the combination of patterns: areas of production facilities, areas of deposit exploitation also with the area of a natural function (14 occurrences); housing functions with the area of service functions (5 occurrences); areas of service development with allotment gardens and arable areas (5 occurrences) and areas of housing development (service, single-family and/or homestead) with the areas of production facilities (4 occurrences). The 'other' category included the following colliding functions: homestead development with single-family housing, housing and service development and surface water areas; housing and service development with closed areas, areas of production facilities with sports and recreation areas and allotment gardens and mining areas with housing and service areas.

When analysing the incompatibilities determined by the field inventory, a similar proportion of individual incomaptibilities can be observed. The largest number of incompatibilities, i.e. as much as $56 \%$ in total, constitute incompatibilities resulting from the neighbouring functions:

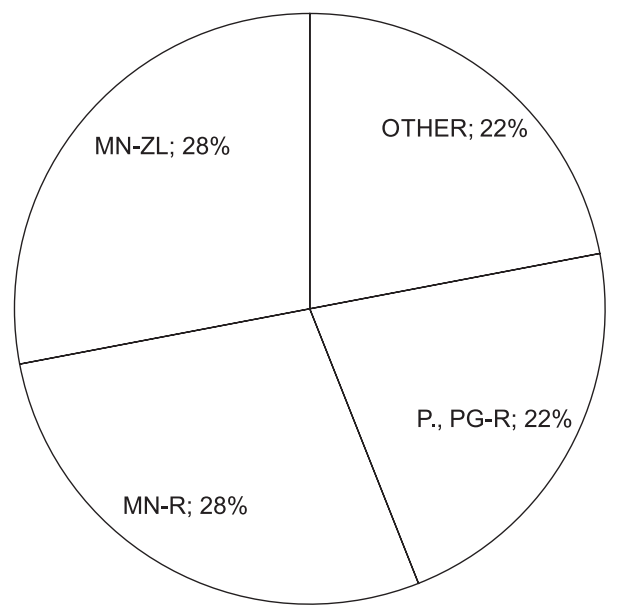

Fig. 3. Share of incompatibilities of land use allocations occurring on the border of the commune of Oleśnica - 2016.

Source: own study based on field inventory.

housing development (single-family housing) with afforestation and with areas used for agricultural purposes. The largest share was held by incompatibilities resulting from neighbouring areas: production facilities, warehouses, mining areas and agricultural areas (4 occurrences) (Fig. 3). The 'other' category accounted for a significant share, which already included one case of adjacent areas: the area of housing development with the area of: large commercial buildings and mining function; the area of civil airport with the area of greenery; homestead development with the area of surface waters.

The studies of spatial development conditions and directions for nine communes were the basic research material. Their scale and quality differed significantly, which made it more difficult to determine the exact lengths of incompatible sections; therefore, individual sections were analysed using general descriptive terms. The incompatibilities concerned short, single fragments of communal boundaries based on the planning documents and field inventory. Longer, incompatible fragments were observed at the junction of the commune and the town of Oleśnica.

\section{Conclusions}

This research shows that there are some spatial dependencies in the occurrence of incompatibilities. To a large extent, areas designated as incompatible appear where incompatibilities 
have been designated on the basis of studies. It simultaneously indicates that actual development incompatibilities are due to spatial planning incompatibilities. This is a premise for the critical assessment of a planning system that could potentially generate a number of problems (e.g. planning incompatibilities, spatial conflicts), while, in line with the principles of spatial order and sustainable development, it should prevent them.

The effect of spatial policies at the local level is the incompatibility of land use allocations, constituting an area of mutual interactions. It is worth noting that space is limited; therefore, in the case of a lack of space with certain characteristics, the appearance of incompatibilities is unavoidable. The analysis showed that the highest concentration of inconsistencies was related to characteristic phenomena of suburbanisation processes (spreading of housing, commercial and service buildings, and road infrastructure).

As a consequence, urban chaos and reduced functional system activity that appear in spatial development lead to the destruction of the natural environment and lower the inhabitants' quality of life. Currently, the intensive development of some functions (housing, services, industry) contributes to the weakening of other functions (arable area, afforestation). Additionally, we can observe the phenomenon of the so-called 'fight for space', i.e. gaining as much space as possible to meet our needs.

The obligatory study of conditions and directions of spatial development creates spatial poli$\mathrm{cy}$, covering the administrative area of the whole commune. When drawing up the documents, there is no obligation to adapt the land use to the neighbouring administrative unit; therefore, the boundaries of communes become particularly vulnerable to incompatibilities and spatial conflicts. On the other hand, according to the Act of 27 March $2003^{3}$, a commune head, mayor or president of a city is only obliged to apply to a neighbouring territorial unit for an opinion on a study project.

The records of land use allocation in the analysed planning studies became the source of incompatibilities occurring in reality. The

Spatial Planning and Land Development Act of 27 March 2003 (Journal of Laws 2003, No 80, item 717). consequence of this is the inhibition of the proper shaping of space and the disturbance of spatial order. When drawing up planning documents, authorities should ensure that the space forms a structured, harmonious whole, which can be achieved through the appropriate cooperation of local spatial policies. It can be stated that a study which is not a local law is not a very effective document, and 'the reason for spatial conflicts is the imprecision of legal regulations' (Grochowska 2016: 120). Constructing high-quality studies and local plans will allow in the future accommodating spatial chaos, which is becoming a critical planning issue.

\section{References}

Allen A., 2003. Environmental planning and management of the peri-urban interface: Perspectives on an emerging field. Environment and Urbanization 15: 135-148.

Antrop M., 2004. Landscape change and the urbanization process in Europe. Landscape and Urban Planning 67: 9-26.

Brown G., Raymond C.M., 2013, Methods for identifying land use conflict potential using participatory mapping. Landscape Urban Plan, http://dx.doi.org/10.1016/j.landurbplan.2013.11.007

Furmankiewicz M., Potocki J., 2004. Przyroda a gospodarka konflikty ekologiczne w zagospodarowaniu przestrzennym Sudetów (The natural environment vs the economy - ecological conflicts over the spatial development of the Sudety mountains). Muzeum Przyrodnicze w Jeleniej Górze: 7-20.

Gołąb-Korzeniowska M., 2008. Konflikty środowiskowe w rozwoju struktury przestrzennej regionu metropolitalnego (Environmental conflicts in the development of the spatial structure of the metropolitan region). Czasopismo Techniczne 5A: 61-73.

Gonda-Soroczyńska E., 2009. Przemiany strefy podmiejskiej Wrocławia w ostatnim dziesięcioleciu (Changes in the suburban zone of Wrocław in the last decade), Infrastruktura i Ekologia Terenów Wiejskich 4/2009, Polska Akademia Nauk Oddział w Krakowie: 149-165.

Grochowska A., 2015. Konflikty przestrzenne w procesie planowania przestrzennego na przykładzie gmin powiatu trzebnickiego (Spatial conflicts in the spatial planning process on the example of communes of the Trzebnica poviat). Studia Miejskie 20: 179-187.

Grochowska A., 2016. Konflikty przestrzenne w planowaniu przestrzennym obszarów metropolitarnych na przykładzie Wrocławskiego Obszaru Metropolitalnego (Spatial conflicts in the spatial planning of metropolitan areas on the example of the Wrocław Metropolitan Area), Rozprawy Naukowe Instytutu i Rozwoju Regionalnego Uniwersytetu Wrocławskiego 38, Wrocław.

Gwiazdowicz M., Zielińska G., 2008. Wyzwania dla polskiej polityki przestrzennej (Challenges for the Polish spatial policy). Konferencja organizowana przez sejmową Komisję Infrastruktury, Ministerstwo Infrastruktury we współpracy z Biurem Analiz Sejmowych Kancelarii Sej$\mathrm{mu}$, Warszawa. 
Hajduk S., 2010. Stan zaawansowania planowania przestrzennego w gminach województwa podlaskiego (State of spatial planning progress in the communes of Podlaskie Voivodeship), Studia Regionalne i Lokalne 1(39)/2010: 105-115.

Jabłoński W., Mazurkiewicz K., 2014. Konflikty przestrzenne na terenach wiejskich-ignorancja czy niewiedza? Studium przypadku Nr IV/2/2014 (Spatial conflicts in rural areas-ignorance or lack of knowledge? Case study IV/2/2014). Polska Akademia Nauk Oddział w Krakowie, Politechnika Wrocławska: 1167-1177.

Jędraszko A., 2008. Gospodarka przestrzenna w Polsce wobec standardów europejskich czyli jak ustanowić dobre prawo dla zrównoważonego rozwoju (Spatial management in Poland in the light of European standards or how to establish a good law for sustainable development), Biblioteka Urbanisty 13, Urbanista, Warszawa.

Kaya A.I., Erol K.N., 2016. Conflicts over locally unwanted land uses (LULUs): Reasons and solutions for case studies in Izmir (Turkey). Land Use Policy 58: 83-94.

Kistowski M., 2008. Problemy lokalizowania inwestycji na terenach cennych przyrodniczo (Problems of locating investments in environmentally valuable areas). In: Gwiazdowicz M. (ed.), Ochrona przyrody, Studia Biura Analiz Sejmowych Kancelarii Sejmu 10. Wydawnictwo Sejmowe Kancelarii Sejmu, Warszawa: 139-163.

Lisowski A., Grochowski M., 2009. Procesy suburbanizacji. Uwarunkowania, formy i konsekwencje (Suburbanisation processes. Determinants, forms and consequences), Ekspertyzy do Koncepcji Zagospodarowania Przestrzennego Kraju, Ministerstw o Rozwoju Regionalnego, Warszawa: 217-280.

Przewoźniak M., 2007. Konflikty w zagospodarowaniu przestrzennym obszaru przybrzeżnego województwa pomorskiego (Conflicts in spatial development of the coastal area of Pomorskie Voivodeship). Proeko, Gdańsk.
Puk M., 2012. Kolizje przestrzenne i konflikty społeczne-gra o przestrzeń-rozwój zrównoważony a równoważenie rozwoju (Spatial collisions and social conflicts-game of space-sustainable development vs development balancing), Studia PAN KPZK CXLII: Gospodarka przestrzenna w świetle wymagań strategii zrównoważonego rozwoju (Spatial management in the light of requirements of sustainable development), Warszawa: 188-195.

Tokajuk J., 2011. Konflikty przestrzenne na styku istniejącej zabudowy zagrodowej i planowanej zabudowy mieszkaniowej na terenach wsi strefy podmiejskiej włączonych do obszaru miasta Białegostoku (Spatial conflicts at the boundary of existing farm buildings and planned housebuilding in the rural areas of the suburban zone included in the city of Białystok), Przestrzen $i$ Forma 15: 311-320.

Ułańska J., Borkowska-Stefańska M., 2012. Użytkowanie ziemi i polityka przestrzenna w Łódzkim Obszarze Metropolitalnym. Spójność terytorialna Łódzkiego Obszaru Metropolitalnego (Land use and spatial policy in the Łódź Metropolitan Area. Territorial cohesion of the Łódź Metropolitan Area). Studia KPZK PAN 147: 14-43.

von der Dunk A., Gret-Regamey A., Dalang T., Hersperger, A.M., 2011. Defining a typology of peri-urban land-use conflicts - A case study from Switzerland. Landscape and Urban Planning 101(2): 149-156.

Wdowicka M., Mierzejewska L., 2012. Chaos w zagospodarowaniu przestrzennym stref podmiejskich jako efekt braku zintegrowanego systemu planowania (na przykładzie strefy podmiejskiej Poznania) (Chaos in the spatial development of suburban zones as a result of lack of an integrated planning system, Problemy Rozwoju Miast: $40-52$.

Zhou D., Lin Z., Lim S.H., 2019. Spatial characteristics and risk factor identification for land use spatial conflicts in a rapid urbanization region in China. Environmental Monitoring and Assessment, https://doi.org/10.1007/s10661019-7809-1 